\title{
Salivary Gland Clear Cell Carcinoma, Not Otherwise Specified
}

National Cancer Institute

\section{Source}

National Cancer Institute. Salivary Gland Clear Cell Carcinoma, Not Otherwise Specified. NCI Thesaurus. Code C62191.

A carcinoma that arises from the salivary glands, most often the minor salivary glands. It is characterized by the presence of a monomorphic population of malignant epithelial cells with clear cytoplasm and the absence of morphologic features that define other primary neoplasms of the salivary glands. 